\title{
Koulutuspaikkoja alkaa olla riittävästi
}

\section{— Riittääkö koulutushalukkuus ja miten se suuntautuu?}

\begin{abstract}
Raivola, Reijo, 1983. Koulutuspaikkoja alkaa olla riittävästi. Aikuiskasvatus 3, 4, 178-182. - Artikkelissa esitellään toisaalta nuorten opiskeluvalintojen perusteita, sekä toisaalta niitä taloudellisia ja sosiaalisia kriisejä, joita esiintyy erityisesti teollistuneissa maissa. Artikkelin lopussa tarkastellaan yleisesti opiskelumotivaatiota ja elinikäisen oppimisen mahdollisuuksia.
\end{abstract}

Otsikon väiteosa tuntuu torjuvan vastaväitteet. Sen vuoksi todettakoon perusteluina:

1. Perusasteella on kyetty 1950 - ja osittain vielä 1960-luvulla huolehtimaan 100000 lapsen ikäluokista. Silloin ei pitäisi 1980-luvulla olla määrällisiä vaikeuksia huolehtia 60000 oppilaan ikäluokista.

2. Keskiasteella on koulutuspaikkoja jo yli kolme kertaa ikäluokan koko (Lehtinen 1980), ja suhdeluku ikäluokkien pienetessä kasvaa. Tavoite ammatillisesti eriytyneestä koulutuspaikasta jokaiselle perusasteen päättäneelle alkaa olla lähellä toteutumistaan.

3. Jos korkea-asteen perustutkinto kestäisi 4---5 vuotta, niin kuin tutkinnonuudistuksen ideana oli, nykyinen paikkamäärä merkitsisi aloituspaikkaa lähes $30 \%$ :lle ikäluokasta.

4. Suurten ikäluokkien ollessa työmarkkinoilla vielä 30 vuotta, suhdeluku työikäisten määrä/kouluikäisten määrä käy yhä suuremmaksi.

Suhteellisesti laskettuna koulutusjärjestelmän ei siis pitäisi kärsiä resurssipulasta. Samoin resurssien opiskelijakohtaisen ohentumisen pitäisi pysähtyä. Kehitys antaisi myös mahdollisuuden koulutusjärjestelmän sisäisten resurssien jakamiseen uudella tavalla. Vai onko käynyt niin, että yhteiskunnalla on hallussaan tehokas instituutio, jossa palvelujen tarjonta ylittää kysynnän? Miten menettelee tuotantolaitos, jonka tuotteet uhkaavat jäädä käsiin? Se supistaa tuotantoaan, ryhtyy polkumyyntiin ja aletarjouksiin, suorittaa tuotekehittelyä $\mathrm{ja} / \mathrm{tai}$ etsii uusia markkinoita.
Muodollisesta kasvatuksesta huolehtiva koulutusyritys voi vastaavasti supistaa järjestelmää vähentämällä koulutuspaikkoja. Esim. Yhdysvalloissa ennustetaan $25 \%$ korkeakouluista häviävän vuosisadan loppuun mennessä (Dunn 1980). Säästyneet resurssit luovutettaisiin muille yhteiskuntapolitiikan sektoreille. Tai järjestelmä voisi tarjota uusia palveluita asiakkailleen: lisää valinnaisaineita, ryhmäjakoja, yksilöllistä opetusta, pidempää koulutusta, monipuolista oppimateriaalia, kehittynyttä opetuksen teknologiaa jne. Se voisi myös houkutella järjestelmän piiriin uusia asiakkaita (esikoulu, aikuiskasvatus, informaalisen koulutuksen organisoiminen osaksi virallista järjestelmää.

Väestökirjanpito ja taloudelliset ennusteet antavat kohtuullisen varoitusajan koulutussuunnittelijalle vaihtoehtojen esittämiseen. On siis poliittisen päätöksenteon asia, mikä vaihtoehto valitaan. Hyvinvoivissa teollisuusmaissa on yleisesti valittu rinnan toteutettavaksi edellä mainituista kaksi viimeistä vaihtoehtoa ja näin tietoisesti luotu koulutukselle kysyntää. Vaikka se on osaltaan antanut aikuiskasvatukselle uusia mahdollisuuksia, on se erityisesti korkea-asteen osalta johtanut ns. koulutuksen inflaatioon. Ilmiötä ei kuitenkaan tule tulkita kasvatuksen vaan ehkä arvosanojen alennusmyyntinä. Näin nuoret ovat asian mieltäneet. Tämä puolestaan on johtanut koulutushaluttomuuteen ja -väsymykseen. Yllättäviä heilahteluja on ollut luettavissa rekrytointiluvuissa eri koulutusaloilla ja -tasoilla. Ruotsista, Keski-Euroopasta ja Yhdysvalloista saadut tiedot kertovat koulutushalukkuuden sel- 
västi laskeneen tai suuntautuneen aloille, joilla odotettu tuotto investointinäkökulmasta katsottuna on pieni (Härnqvist 1978). Koulutus-ja ammattirakenteen välillä vallitsee sekä krooninen että aika ajoin toistuva akuutti epätasapaino. Ihminen ei aina toimi koulutusvalintoja tehdessään rationaalisesti konjuktuureja ennakoiden. Koulutuksen sosiaalinen (=yksilöllinen) kysyntä on siis tekijä, joka selvästi vaikeuttaa koulutussuunnittelijan työtä. Koulutushaluttomuuden syiden etsiminen on tärkeää myös jatkuvan koulutuksen toteutumisen kan- nalta. Lapsuus- ja nuoruusiässä muodostunut negatiivinen asenne oppimista kohtaan saattaa muodostaa voittamattoman esteen aikuisiän järjestelmälliselle oppimiselle.

Asiaan vaikuttavia tekijöitä voidaan analysoida esim. seuraavan mallin avulla. Tarkoin on kuitenkin analyysissa erotettava kolme käsitettä toisistaan: koulutustarve / koulutuskysyntä / koulutushalukkuus. Varsinkaan kysyntää ei pidä sekoittaa halukkuuteen. Tällä hetkellä koulutusseurakunnan nuoremmista jäsenistä suuri osa on agnostikkoja ja tapajäseniä. (Ks. Ruohotie \& Raivola 1983.)

Kuvio 1. Koulutuksen sosiaaliseen kysyntään yhteydessä olevat tekijät

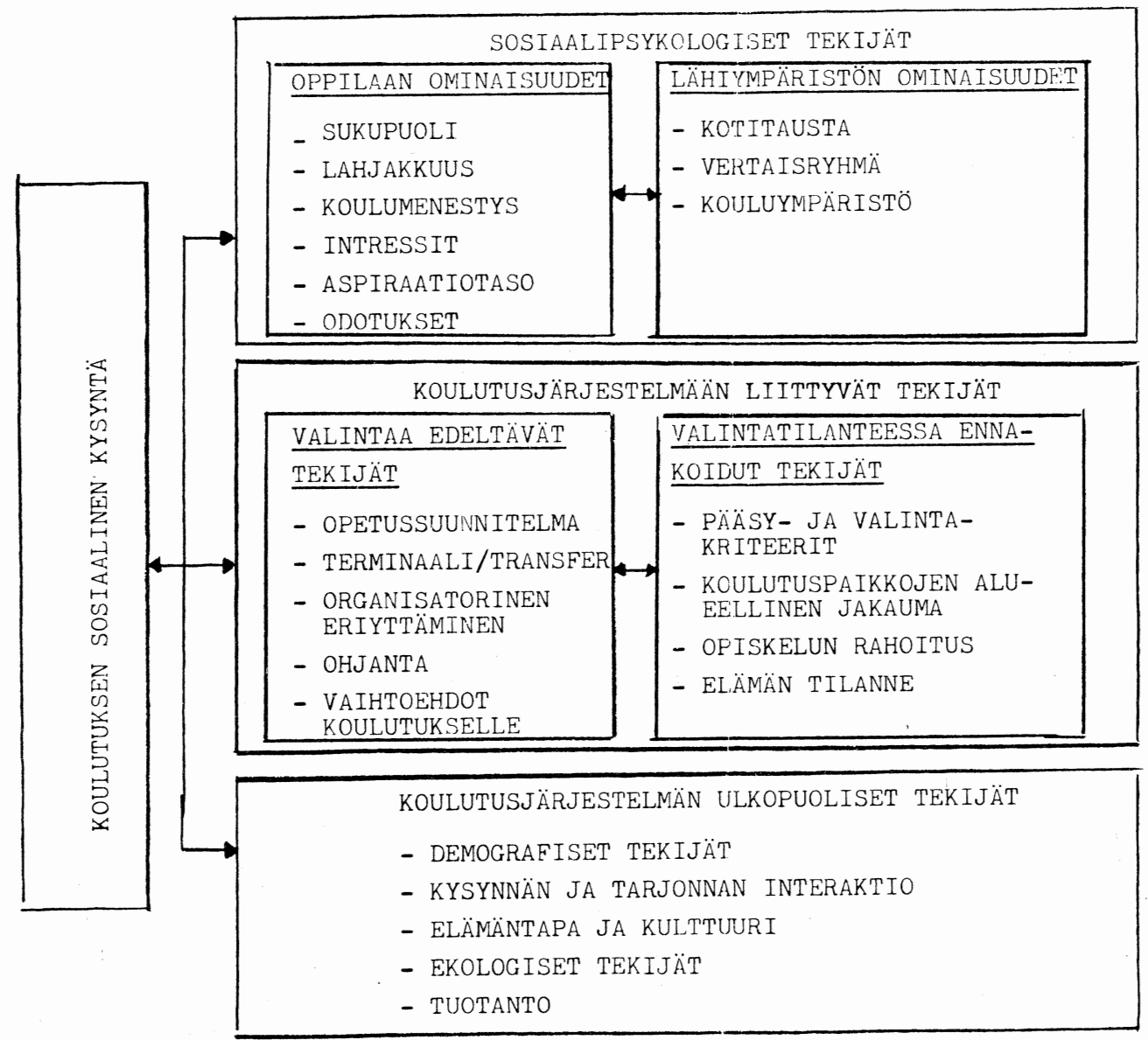




\section{Sosiaalipsykologiset tekijät}

Nuoren kansalaisen/kuluttajan ja toisaalta koululaisen/opiskelijan roolien välillä vallitsee valtava ristiriita. Nuoria pidetään lähes kolmenkymmenen ikään asti sosiaalisessa, psykologisessa ja taloudellisessa pakkopuberteetissa, koska he ovat Husenin termiä käyttääksemme käyneet funktionaalisesti tarpeettomiksi. Samalla nuoret huomaavat koulutusmaalin karkaavan ulottuviltaan. Tämä laskee niitä objektiivisia odotuksia, joita heillä koulutuksen ostovoimasta on ollut. Analyyttisesti onkin tärkeätä pitää erillään toisistaan nuorten subjektiivinen aspiraatiotaso, jonka ei tarvitse ottaa huomioon reaalimaailman rajoitteita, ja objektiiviseen todellisuuteen pidättyvät odotukset.

Tähänastinen koulutuskysynnän kasvu on pitkälti perustunut malthuslaiseen geometriseen kasvuun: mitä enemmän yleissivistävää koulutusta on hankittu sitä enemmän sitä tulevaisuudessa on kysytty. Mutta pian lastensa koulutuksesta on päättämässä ensimmäinen sukupolvi, joka ei olekaan täysimittaisesti pystynyt taloudellisesti hyödyntämään koulutusetuaan. Koulutusevankeliumi on osittain menettänyt uskottavuuttaan. Eräässä mielessä vastaan on tullut ainakin yksijaksoisen koulutuksen koulutuskatto.

Koulutus merkitsee tiedon siirtämistä, tuttua ja turvallista vanhan jatkamista ja kenties kehittämistä. Mutta ihminen haluaa oppia todella uutta. Hän haluaa itse muodostaa tietoa. Ihminen on pohjimmiltaan löytöretkeilijä ja seikkailija. Hän ei halua tulla pelkästään sosiaalistetuksi ja akkultturoiduksi (vrt. nuorison kapinointi joka sukupolvessa). Hän haluaa itse asettaa omat tavoitteensa. Kasvatuksella on mahdollisuutensa vain silloin, kun oppija henkilökohtaisesti hyväksyy tavoitteet ja tunnustaa kasvatuspäämäärän. Työ institutionalisoidun kulttuurinsiirtotehtaan liukuhihnalla sitä vastoin vieraannuttaa.

\section{Koulutusjärjestelmään liittyvät tekijät}

Opetussuunnitelmat ovat voimakkaasti menneisyyteen orientoituneita. Kuitenkin maapallon väestöstä on puolet alle 20 -vuotiaita. Nuorelle ensimmäinen kuukävelijä on yhtä todellinen kuin Kolumbus tai Kennedy ja yhtä tärkeä kuin Caesar. Nuoret haluavat ymmärtää huomista, koska heidän on elettävä huomisessa. Koulutuksella on oltava välitöntä käyttöarvoa nuorelle hänen elämäntilanteessaan.
Se sinänsä oikea oivallus, että lapsuuden ja nuoruuden pohjakoulutuksella luodaan valmiudet jatkuvaan oppimiseen ja persoonalliseen kasvuun, saattaa väärin painotettuna nähdä nuoret vain mahdollisina rekryytteinä aikuiskoulutukseen, jossa vasta "totuus" paljastuu.

Turhauttava on myös yleissivistävän ja ammatillisen koulutuksen välinen ristiriita. Nuoret haluaisivat ammatillista koulutusta, mutta hankkivat yleissivistävää, koska näin negatiivinen valinta estyy: pidetään kaikki mahdolliset väylät avoinna mahdollisimman pitkään. Kaikkineenkin työn ja koulutuksen suhde on ongelmallinen. Aikuisilla on yhä tunnustetumpi oikeus opiskeluun ja paranevat mahdollisuudet realisoida tuo oikeus. Nuoret selvästi haluavat oikeuden työhön. Tärkeässä asemassa on yhteiskunnan nuorille ohjaama taloudellinen tuki: onko se opintososiaalista koulunkäyntiään ja opiskeluaan jatkaville vai suoraa kulutusta edistävää tukea välillä koulutuksensa keskeyttäneille. Ehkä nuoret koulutusoikeuden ohella tarvitsisivat myös yhteiskuntatakuun, joka oikeuttaisi työhön ja oikeudenmukaiseen kulutustasoon. Jaksottaiskoulutuksen ideaa voisi kehitellä muultakin pohjalta kuin OECD:n taloudellisen hyödyn maksimoinnin pohjalta. (Ks. Mietintö 1983, 14-17.)

Kaikki eivät halua koulutuskilpailussa juosta samaa matkaa, jossa lähtö ja maali ovat kaikilla samassa paikassa ja joka on kaikkien juostava samanlaisella vauhdilla. Tosi, oikea ja tärkeä ovat suhteellisia ja yksilöllisiä käsitteitä, jotka halutaan realisoida muuallakin kuin koulussa. Jatkuvan koulutuksen komitea on oikein oivaltanut tämän laajan käsityksen horisontaalisesta integroinnista. Tiedon pirstaleet eivät nuoria kiinnosta. He haluavat integroituja kokonaisohjelmia persoonallisuutensa kehittämiseksi. Kukaan ihminen ei halua koko ikäänsä olla potentiaalinen kyky. Hän haluaa myös toteuttaa mahdollisuutensa: tehdä, luoda, saada aikaan, onnistua. Pitäisikö perustavoitteet määritelläkin minimitavoitteiden asemesta maksimitavoitteina? Tämä ei kuitenkaan saisi merkitä yhteiskunnallisen tehokkuuden maksimointia vaan haasteita yksilölliselle suorituskyvylle. Kilpailuyhteiskunta opettaa pelkäämään ja kadehtimaan muitten taitoja. Tuen etsimisen ja yrittämisen sijasta vetäydytään psyykkiseen eristäytyneisyyteen ja rationalisoidaan yrittämisen puute: siinä ei voi epäonnistua, mitä ei edes yritä.

Koulu on työvoimavaltaisin yritys uudenaikaisessa informaatioyhteiskunnassa. Yleissivistävässä opetuksessa tehdään joka tunti käsi- 
työtä, vaikka muualla hallitsee jo piin siru. Uudet välineet ja ideat saavuttavat usein koulun vasta, kun niitä vanhentuneina ollaan muualla jo hylkäämässä. Kokevatko ja muistavatko nuoret koulun paikkana, jonka ikkunoista on hyvä näköalapaikka katsella kehityksen lipuvan ohi?

\section{Koulutusjärjestelmän ulkopuoliset tekijät}

Pessimistisimmät (tai optimistisimmat) arviot laskevat, että $15 \%$ väestöstä pystyy huolehtimaan yhteiskunnan taloudellisesta perustasta. Mikä on silloin työtä vailla olevien ihmisten elämän perusta? Mistä he saavat omanarvontuntonsa ja arvokkuutensa? Olisiko erotettava toisistaan (palkka) työ ja tekeminen? Kun edellistä ei rationalisoinnin ja automatisaation aikana riitä kaikille, miksi silloin uskotella, että työn puute on tilapäistä ja että mitä enemmän siihen koulutetaan sitä enemmän sitä jostakin löytyy tehtäväksi. Mielekästä tekemistä sen sijaan riittää kaikille: koulutetaan ihminen toimimaan (vapaa-aikaan). Syytökset odotuksia laskevasta cooling-politiikasta ovat menettäneet kärkensä. Työn ja koulutuksen suhdetta on mietittävä uudella tavalla.

Yhteiskuntaa koettelevat maapallon laajuiset taloudelliset ja sosiaalipoliittiset kriisit. Minkä kokee yksilö asemansa olevan yleisessä myllerryksessä? Johtaako lisääntyvä voimattomuuden tunne lopulliseen passiivisuuteen, psykologiseen invaliditeettiin (Illich 1972), vai rajuun kapinaan, joka ravistelee kaikkia instituutioita, koulua ensimmäisenä? Auktoriteettien ja järjestelmien uskottavuuden puute on tällä hetkellä ilmeinen (vrt. Galtung 1973). Onko seurauksena vasta- ja vaihtoehtoisten kulttuurien syntyminen? Pehmeän teknologian ja solidaarisen yhteiskunnan puolestapuhujat korostavat voimakkaasti elintason ja elämisen tason välistä osittaista ristiriitaa. Taloudellinen hyvinvointi on heidän mielestään johtanut kansalaiset henkiseen pahoinvointiin, vastuuntunnon puutteeseen ja ikuiseen puberteettiin. Yhtenä syynä suunnan puutteeseen on yleinen arvojen ristiriita (uskonto, perhe, suoritusmotivaatio, ryhmäedut, politiikka jne.).

\section{Johtopäätöksiä ja väitteitä edellisestä}

Kaikesta yksilöllisestä epäilystä huolimatta muodollisia kelpoisuuksia antavan koulutuksen kysyntä jatkuu maassamme edelleen voimakkaana. Syitä on useita. Koulutuksen pi- dentäminen ja koulutusetujen lisääminen ovat vaihtoehtoja (nuoriso)työttömyydelle. Koko yhteiskunta, mutta varsinkin julkinen sektori, toimii puhtaan meritokraattisesti: ilman arvosanojen antamaa kelpoisuutta ei ole täyttä kansalaisoikeutta. Vaikka koulutus ei ole riittävä ehto elämässä menestymiselle, on se silti välttämätön edellytys. Lisäksi oppilaitokset ja opettajat ovat jo olemassa, ja opettajat ammattiyhdistysaktiiveina pitävät kiinni saavutetuista eduista, jotka yleensä määritellään määrällisinä. Oppilaana oleminen vähentää vastuuta omasta elämästään, varsinkin kun ihminen yleensäkin on institutionalisoitunut. Hänellä ei ole nykyisyyttä eikä tulevaisuutta instituutioiden ulkopuolella. Vain rohkeimmat uskaltavat olla yksilöitä. Yhteiskunta tukee voimakkaammin koulunkäyntiä kuin opiskelua. Eräs syy koulutuksen kasaantumiseen saattaa olla juuri tässä. Nykyinen koulutusjärjestelmä kokonaisorganisaationa tarjoaa hyvät hyväksikäyttömahdollisuudet koulutuksen "'järjestelmäekspertille", ts. sellaiselle, joka on oikein oppinut reagoimaan järjestelmän odotuksille. Hänet luokitellaan nopeaksi oppijaksi ja jatkokoulutuksella hyödynnettäväksi yksilöksi, jonka kuvan hän myös itse sisäistää ja näin yhdessä järjestelmän kanssa toimii itseään toteuttavana ennusteena. Suomalainen yhteiskunta on keskiluokkaistunut, ja keskiluokan arvomaailmaan on perinteisesti kuulunut ei niinkään taitamisen ja osaamisen kuin muodollisen koulutuksen arvostaminen. Jatkuvan koulutuksen komitean ajatus horisontaalisesta integroinnista on keskeinen keino pyrittäessä vaikuttamaan koulutusedun kasautumiseen. $\mathrm{Se}$ on vain ymmärrettävä niin laajasti, että nuorisoasteellakin on mahdollista saada elinikäisen oppimisen kannalta tarpeelliset perusvalmiudet muutakin tietä kuin perinteisesti koulua käymällä.

Koulutuskysyntä näyttää edelleenkin suuntautuvan enemmän yleissivistävään kuin ammatilliseen peruskoulutukseen. Keskiasteen uudistuksen avaama väylä korkeakouluopintoihin koetaan sittenkin kiertotienä koulutusmaaliin. Voimakkaampi kysyntä kuitenkin kohdistunee aikuiskoulutukseen (avoin korkeakoulu-, kansalais- ja työväenopistot, opintokerhot ja kesäyliopistot). Mikroprosessorien ajasta huolimatta ihmiset haluavat humanistista ja harrastuspainotteista koulutusta.

Myös virallisen koulutusjärjestelmän, tarkoin vertikaalisesti integroitavan koulutusputken, mahdollistamat harvat vaihtoehdot herättävät kiinnostusta (Steiner-koulu, vieraskieliset lastentarhat ja koulut, erityislukiot, kau- 
pallinen koulutustarjonta). Kuitenkin ihmiset odottavat koulutuksensa lisäävän jollakin tavalla heidän muodollista pätevyyttään. Tämä johtaa pedagogiseen ristiriitaan arvosana- ja suoritusjärjestelmän laajentamisen ja opiskelun sisäisen motivaation välillä. Työaikana saatava ja työnantajan maksama (myös yleissivistävä) koulutus laajenee osana henkilöstökoulutuksen entistä laajempaa määrittelyä.

Koulutushaluttomuutta vastaan voidaan taistella rakentamalla yksilölliset ja kokonaispersoonallisuutta integroivat kasvatuksen tavoiteohjelmat ja lopettamalla koulutuksen myyminen investointina taloudellisen hyödyn saamiseksi tulevaisuudessa. Esim. Döger (1976) on laskenut, että Länsi-Saksan työvoimasta $25 \%$ ei tarvitse minkäänlaista muodollista koulutusta selviytyäkseen työtehtävistään. Tämä polarisaation määrällinen arvio lienee ylimitoitettu, mutta selvää myös on, että jokaiselle koulutetulle ei riitä mielenkiintoista ja henkisesti palkitsevaa työtä ja että työelämään siirtymisprosessi käy yhä pidemmäksi. Elinikäisen kasvatuksen idean mukaista on, että koulutusta saa silloin, kun yksilö tuntee sitä tarvitsevansa ja osin sellaisena kuin hän haluaa. Koulutuksen vapauttaminen tiukasti valvotusta muodollisesta järjestelmästä lisää omaehtoisuutta opiskelussa. Opetuksen kehittyvä teknologia antaa aivan uusia mahdollisuuksia oppimisen organisoimiseen. Samoin yhdysvaltalaiset käsitteet community college ja paracurriculum, jotka merkitsevät oppilaitoksen sitomista lähiympäristön ongelmien ratkaisemiseen ja opetussuunnitelman ulkopuolisen, välittömästi tarpeellisen aineksen joustavaa käyttöä oppisisältöinä, lisäävät koulutuksen relevanssia.

Suhteellinen arvostelu on sopimaton, jos tavoitteena on persoonallisuuden kasvu. Se johtaa kilpailuun toisten kanssa, kun koulutuksen päin vastoin pitäisi vastata henkilökohtaisiin haasteisiin ja ongelmiin. Usein sanotaan, että opetuksen tulee olla ongelmakeskeistä. Mutta oppijalla ei ole mielekkäitä ongelmia, ennen kuin hän on hankkinut perspektiiviä yhteiskuntaan ts. aitoja työ- ja elämänkokemuksia. Ei siis ole ihme, että aikuisen opiskelumotivaatio on oppivelvollisen motivaatiota suurempi. Kenties oppivelvollisuus olisikin päätettävä 15-16 vuoden iässä, minkä jälkeen taattaisiin oikeus itsensä kehittämiseen ja jatkuvaan kasvuun. Pohjakoulun 'kolme ärrää' (the 3 R's: reading, writing, (a)ritmetics) vaihdetaan kolmeksi E:ksi: exitement, entertainment ja education. Tämähän tilanne on jo pitkään ollut aikuiskasvatuksessa. Koulujärjestelmässä on aikuiskoulutuksen tapaan annettava koulutusvastuuta myös muille kuin opetuksen asiantun- tijoille, esim. vertaisille (oppilaissa on usein jonkin erikoisalan todellisia eksperttejä), talous- ja kulttuurielämän asiantuntijoille sekä ihmisen tuntijoille. Jatkuvan koulutuksen toteuttaminen merkitsee kilpailun vähentämistä siinä, että tavoitteet lakataan sitomasta aikaan.

Koulutusorganisaation on myös omaksuttava osavastuu yksilön allokoinnista täysivaltaiseen elämään. Aikuisopiskelijan kohdalla on pystyttävä voittamaan pohjakoulutuksen luomat kielteiset opiskeluasenteet ja aikaisempien oppimiskokemuksien puutteellisuus (hakeva toiminta, opintopiiri, etäopetus, opetuksen teknologia, työpaikan yleissivistävä koulutus, kansalaisloma opiskelua varten jne.) niin, että oppija tuntee saavuttavansa vaativampaa koulutusta varten tarpeelliset perusvalmiudet. Jatkuvan koulutuksen toimikunnan mietintö antaa järkevän perustan koulutuksen kehittämiselle koko eliniän jatkuvan oppimisen tukijana. Tämä toivo nojaa toimikunnan antamaan määritelmään: "'Toimikunta käyttää käsitettä 'jatkuva koulutus' kuvaamaan elinikäistä oppimista erityisesti koulutusjärjestelmän kehittämisen kannalta." (Mietintö 1983,6.)

\section{Lähteet}

Coates J. 1980. Population and Education. - Jennings L. \& Cornish S. (toim.): Education and the Future. Washington: World Fut. Society

Dunn S. 1980. The Case of Vanishing Colleges. Jennings \& Cornish (toim.) Education and Future. Washington: World Future Society.

Döger U. 1976. Veränderungsstrategien und Legitimationsmunster in der Schulereformdiskussion der BRD. Frankfurt am Mein.

Galtung J. 1973. Educational Planning and Educational Research. - Long-Range Policy Planning in Education. Pariisi: OECD.

Härnqvist K. 1978. Individual Demand for Education. Pariisi: OECD.

Illich I. 1972. Kouluttomaan yhteiskuntaan. Helsinki: Otava.

Lehtinen J. 1980. Havaintoja keskiasteen koulutuksen alueellisen jakauman kehityksestä Suomessa vuosina 1967-1977. - Siirilä S. ym. (toim.): Kylät ja kaupunginosat. Tampere: Finnpublishers.

Mietintö 1983. Jatkuvan koulutuksen toimikunnan mietintö. Helsinki.

Ruohotie P. \& Raivola R. 1983. Koulutushalukkuudesta ja koulutuksen sosiaalisesta kynnyksestä. - Näkemyksiä koulutuksen tulevaisuudesta, asiantuntijaselvityksiä koulutussuunnittelun neuvottelukunnalle, osa II. Helsinki.

Share H. 1980. Education for Tomorrow's World. - Jennings \& Cornish. (toim.). Education and the Future. Washington, World Fut. Society.

Strom R. 1980. Education dor the Leisure Society. - Jennings \& Cornish (toim.). Education for the Future. Washington: WFS. 